\title{
Stability and breeding potential of tomato hybrids
}

\author{
Enrique Hernández-Leal ${ }^{1}$, Ricardo Lobato-Ortiz ${ }^{*}$, J. Jesús García-Zavala², \\ Aurelio Hernández-Bautista², Delfino Reyes-López ${ }^{3}$, and Olga Bonilla-Barrientos ${ }^{1}$
}

\begin{abstract}
'Instituto Nacional de Investigaciones Forestales, Agrícolas y Pecuarias (INIFAP), Centro de Investigación Regional Norte Centro (CIRNOC), Av. José Santos Valdez No. 1200 Pte. 27440, Col. Centro, Matamoros, Coahuila, México.

${ }^{2}$ Colegio de Postgraduados, Campus Montecillo, km 36.5 Carr. México-Texcoco, 56230, Texcoco, Estado de México, México. "Corresponding author (rlobato@colpos.mx).

${ }^{3}$ Benemérita Universidad Autónoma de Puebla, Facultad de Ingeniería Agrohidráulica, Av. Universidad s/n, 73695, Teziutlán, Puebla, México.
\end{abstract}

Received: 10 August 2018; Accepted: 8 December 2018; doi:10.4067/S0718-58392019000200181

\begin{abstract}
Commercial tomato (Solanum lycopersicum L.) hybrids can be a good germplasm for obtaining new tomato inbred lines. The present study was aimed to investigate the stability of commercial $F_{1}$ hybrids under climatic conditions of highlands, to estimate genetic parameters, and evaluate the breeding potential of $F_{1}$ hybrids based on the agronomic performance of its $\mathrm{F}_{3}$ progeny. We employed a breeding scheme based on pedigree selection for the obtainment of $49 \mathrm{~F}_{3}$ families. Significant differences were found in most of the traits evaluated in both $F_{1}$ and $F_{3}$ generations, while in the $F_{2}$ population only one variable showed significant differences. Heritability ranged from 0.07 to 0.29 for $F_{1}$, and from 0.16 to 0.45 for $F_{3}$. Most of the $F_{1}$ hybrids exhibited values of stability across seasons in at least one trait. However, 'Loreto' and 'Reserva' only exhibited a high stability for yield. Genetic gains ranged from -8.40 to 72.95 . Yield per plant was the traits with the highest gain. Based on genetic gains obtained by the $\mathrm{F}_{3}$ progeny, we concluded that 'Cid', 'Espartaco' and 'Loreto' have a high breeding potential for yield and other traits, which could be exploited by public tomato breeding programs.
\end{abstract}

Key words: Genetic gain, heritability, Solanum lycopersicum, stability, tomato breeding.

\section{INTRODUCTION}

In Mexico, tomato (Solanum lycopersicum L.) production has increased by 50\% due to protected agriculture and new varieties, which has given advantages to growers to increase their yield per hectare (SAGARPA, 2017). Tomato production generates large incomes for the Mexican producers as most of their production is exported to the United States of America (FAO, 2014). According to Fisheries and Agrifood Information Service from Mexico (SIAP, in Spanish), the annual tomato production was around 2.8 million tons, of this amount, exportations accounted for nearly $\$ 2$ billion (SIAP, 2015).

Tomato breeding programs are directed towards the development of cultivars for the fresh market and for processing (Foolad and Panthee, 2012). Although cultivars for both markets are different in some traits, the common goal in the tomato breeding programs is the achievement of higher yields. Recently, efforts are focused on creating new improved varieties for high content of antioxidants such as lycopene, beta-carotene, and vitamin C (Masheva, 2014).

Previous studies in tomato reported that the additive effects are more predominant in the inheritance of yield per plant, number of fruits per plant and number of fruits per truss (Kumar et al., 2013; Martínez-Vázquez et al., 2017). For this reason, the generation of inbred lines for obtaining new high-yielding hybrids is a very successful methodology and widely used by breeders. In tomato, selection by pedigree is considered as an effective strategy to generate inbred lines with increased yield, as in each generation positive alleles are accumulated by the natural process of self-fertilization. This methodology consists in the individual selection of plants in successive generations, where the detailed records of the origin of the selected genotypes are maintained (Acquaah, 2012). However, novel selection strategies have been 
proposed to exploit the heterosis through a recurrent selection scheme. In this sense, Avdikos et al. (2011) demonstrated that the recurrent selection of tomato followed by the formation of half-sib's families generated an increase in yield due the accumulation of favorable alleles and heterosis.

The use of commercial varieties for generation of diversity is a common methodology applied in many tomato public breeding programs. Early works of rice (Nalley et al., 2016), showed that progeny derived from commercial parents exhibited improved traits, suggesting that this parent-type is a profitable source for the generation of elite material. Little information exists on breeding potential of commercial tomato varieties for obtaining of new lines via pedigree selection. Given the importance of knowing the breeding value of parents and other important genetic parameters in tomato improvement, it is necessary to investigate the breeding potential of commercial tomato varieties. Therefore, the objectives of this study were to know the stability of seven tomato modern cultivars, to study the heredity and variability of seven traits, and to evaluate their breeding potential based on the performance of their $\mathrm{F}_{3}$ progenies.

\section{MATERIALS AND METHODS}

\section{Plant material and breeding scheme for obtaining $\mathbf{F}_{3}$ families}

The genetic material consisted of seven saladette-type tomato $F_{1}$ hybrids of indeterminate growth: 'Moctezuma', 'Cuauhtémoc', 'Espartaco', 'Cid', 'Sun7705', 'Loreto', and 'Reserva', and their $\mathrm{F}_{2}$ and $\mathrm{F}_{3}$ generations. The experiments were conducted from 2015 to 2016 and were evaluated under greenhouse conditions at Montecillo $\left(19^{\circ} 30^{\prime}\right.$ N, $98^{\circ} 53^{\prime}$ W; 2250 m a.s.1.), Texcoco, State of Mexico, Mexico.

For the obtaining of best $\mathrm{F}_{3}$ families, we employed the pedigree selection. Specifically, in the first year, the seven $\mathrm{F}_{1}$ hybrids were planted during the spring-summer crop cycle of 2015 and evaluated in a randomized complete block design with four replicates and 10 individuals per replicate. After, plants were covered with glassine bags. When the pollinized fruits presented physiological maturity, their seeds $\left(\mathrm{F}_{2}\right.$ population) were extracted and dried using paper towels. For a second season, a total of 14 entries were planted; seven $F_{1}$ hybrids and seven $F_{2}$ populations. This experiment was performed during the fall-winter season of 2015 and was conducted under a randomized complete block design with four replicates. Here, each replicate for $F_{1}$ hybrids was represented by 10 plants while the $F_{2}$ population by 25 plants. The best seven plants of each $\mathrm{F}_{2}$ population were chosen according to the following criteria: high yield, oval shaped fruit, high average fruit weight, and good level of sanity. Therefore, a total of seven $\mathrm{F}_{3}$ families per each $\mathrm{F}_{2}$ population were obtained. Finally, the evaluation of the three generations was performed during the spring-summer season 2016. The studied population consisted of seven $F_{1}$ hybrids, seven $F_{2}$ population and $49 F_{3}$ families. Similarly, the experiment was conducted under a randomized complete block design with four replicates. Each replicate consisted of 10 plants.

\section{Data collection}

During the phenotyping, harvest of fruits was performed at 82,94 , and $136 \mathrm{~d}$ after transplantation. In each harvest, seven traits were scored: number of fruits per plant, yield (g), number of trusses, number of fruits per truss, average fruit weight $(\mathrm{g})$, fruit diameter $(\mathrm{cm})$, and fruit length $(\mathrm{cm})$. Yield and number of fruits per plant were obtained weighting and counting the total number of harvested fruits by each plant. Number of trusses was measured counting total trusses per plant at $136 \mathrm{~d}$. Number of fruits per truss was scored as the average of fruits produced in the second and third truss. Average fruit weight, diameter and length were obtained from a sample composed of five fruits per plant.

\section{Statistical analysis}

ANOVA and comparison of means were performed for each generation using the general linear model (PROC GLM) and Tukey's test $(P \leq 0.05)$, respectively. In particular, the phenotypic data of $F_{1}$ generation were analyzed using the following model:

$$
y_{i j k}=\mu+s_{i}+g_{j}+g s_{i j}+b_{k}\left(s_{i}\right)+\varepsilon_{i j k}
$$

where $y_{i j k}$ is the observed value of the $\mathrm{j}^{\text {th }}$ hybrid in the $\mathrm{k}^{\text {th }}$ replicate of the $\mathrm{i}^{\text {th }}$ season, $\mu$ is the population mean, $s_{i}$ is the $\mathrm{i}^{\text {th }}$ season effect, $g_{j}$ is the $\mathrm{j}^{\text {th }}$ hybrid effect, $g s_{i j}$ is the effect of $\mathrm{j}^{\text {th }}$ hybrid by $\mathrm{i}^{\text {th }}$ season interaction, $b_{k}\left(s_{i}\right)$ is the effect of $\mathrm{k}^{\text {th }}$ replication nested to $\mathrm{i}^{\text {th }}$ season, and $\varepsilon_{i j k}$ is the residual effect with $\sim N\left(0, \sigma \frac{2}{\varepsilon}\right)$. 
For $F_{2}$ populations, a similar model to that used for $F_{1}$ was performed, however, it was added the variation source of individuals nested to populations. Concerning the $\mathrm{F}_{3}$ families, we used the following model:

$$
y_{i j}=\mu+b_{i}+g_{j}+\text { individuals }\left(g_{j}\right)+\varepsilon_{i j}
$$

where $y_{i j}$ is the observed value of the $\mathrm{j}^{\text {th }}$ family in the $\mathrm{i}^{\text {th }}$ replicate, $\mu$ is the population mean, $b_{i}$ is the effect of $\mathrm{i}^{\text {th }}$ replication, $g_{j}$ is the $\mathrm{j}^{\text {th }}$ family effect, individuals $\left(g_{j}\right)$ is the within family effect, and $\varepsilon_{i j}$ is the residual effect with $\sim N\left(0, \sigma_{\bar{\varepsilon}}\right)$.

The estimation of variance components and broad-sense heritability were obtained using the expected mean squares. All previous tests were conducted using SAS statistical software V9 (SAS Institute, 2011). To know the breeding potential of $F_{1}$ cultivars, gain genetic was calculated across generations. Genetic gain was estimated by:

$$
\Delta_{G}=\left(\frac{x_{F_{j}}-x_{F_{i}}}{\bar{x}_{F_{i}}}\right) * 100
$$

where $\Delta_{G}$ is the observed genetic gain, $\bar{x}_{F_{j}}$ is the mean of progeny population derived from parental population i, and $\bar{x}_{F_{i}}$ is the mean of parental population i.

\section{RESULTS}

\section{ANOVA and genetic parameters}

ANOVA detected significant difference $(P \leq 0.05)$ between $F_{1}$ varieties for the factor genotypes in all traits, while for $F_{3}$ families, traits as number of fruits per plant, yield per plant, number of trusses, average fruit weight, fruit length and fruit diameter exhibited significant differences. Concerning $\mathrm{F}_{2}$, ANOVA only detected significant differences in fruit diameter. For this reason, variance components are only reported for both $F_{1}$ and $F_{3}$ generations (Table 1). In general, most of the observed phenotypic variance was due to non-genotypic effects. Such results were confirmed with the heritability estimates, which were less than 0.5 . Specifically, heritability ranged from 0.07 to 0.29 for $F_{1}$, and from 0.16 to 0.45 for $F_{3}$.

Coefficient of variation is an important statistical parameter for the comparison of phenotypic variation between traits. Regarding to the coefficient of variation, the values were very similar between $F_{1}$ and $F_{3}$ generations. However, a higher variation was found in the number of fruits per plant and yield per plant than for fruit related-traits. In addition, traits as number of trusses and fruits per truss had a coefficient of variation greater than $20 \%$. On the other hand, coefficient of variation due to genotypic effects was different between generations, being $F_{3}$ values higher than those in the $F_{1}$ generation.

\begin{tabular}{|c|c|c|c|c|c|c|c|c|c|c|c|c|}
\hline \multirow[b]{2}{*}{ Generation } & \multirow[b]{2}{*}{ Trait } & \multicolumn{4}{|c|}{ Factors } & \multicolumn{4}{|c|}{ Variance estimates } & \multirow[b]{2}{*}{$\mathrm{H}^{2}$} & \multirow[b]{2}{*}{$\mathrm{CV}_{\mathrm{P}}$} & \multirow[b]{2}{*}{$\mathrm{CV}_{\mathrm{C}}$} \\
\hline & & Season & $\begin{array}{c}\text { Block } \\
\text { (Season) }\end{array}$ & $\begin{array}{l}\text { Season } \times \\
\text { Genotype }\end{array}$ & Genotype & Genotypic & $\begin{array}{l}\text { Genotype } \\
\times \text { Season } \\
\text { interaction }\end{array}$ & Error & Phenotypic & & & \\
\hline \multirow[t]{8}{*}{$\mathrm{F}_{1}$} & Yield per plant & $* * *$ & $* *$ & $* *$ & $* * *$ & 124413.21 & 237941.50 & 606734.00 & 810461.05 & 0.15 & 36.55 & 16.55 \\
\hline & Number of fruits per plant & $* * *$ & & $* * *$ & $* * *$ & 10.86 & 95.25 & 53.00 & 95.61 & 0.11 & 27.18 & 12.30 \\
\hline & Number of trusses & & $* * *$ & $* * *$ & $* * *$ & 0.07 & 0.43 & 0.74 & 0.95 & 0.08 & 30.86 & 9.65 \\
\hline & Fruits per truss & $* * *$ & & & $* * *$ & 0.23 & 0.81 & 2.95 & 3.46 & 0.07 & 24.20 & 6.81 \\
\hline & Average fruit weight & $* *$ & $*$ & $* *$ & $* * *$ & 72.08 & 183.00 & 425.30 & 558.38 & 0.13 & 17.69 & 7.28 \\
\hline & Fruit length & $* * *$ & & $* *$ & $* * *$ & 0.16 & 0.12 & 0.35 & 0.54 & 0.29 & 8.59 & 5.80 \\
\hline & Fruit diameter & $* * *$ & & & $* * *$ & 0.02 & 0.03 & 0.16 & 0.20 & 0.12 & 8.45 & 3.14 \\
\hline & & & Block & $\begin{array}{c}\text { Family } \\
\text { (Individual) }\end{array}$ & Families & Genotypic & & Error & Phenotypic & $\mathrm{H}^{2}$ & $\mathrm{CV}_{\mathrm{P}}$ & $\mathrm{CV}_{\mathrm{G}}$ \\
\hline \multirow[t]{7}{*}{$\mathrm{F}_{3}$} & Yield per plant & & $* * *$ & $* * *$ & $* * *$ & 105752 & - & 336743.00 & 510158 & 0.21 & 40.66 & 22.79 \\
\hline & Number of fruits per plant & & & $*$ & $*$ & 12 & - & 49.30 & 69.19 & 0.17 & 38.58 & 19.03 \\
\hline & Number of trusses & & & $* *$ & $* * *$ & 0.307 & - & 1.37 & 1.883 & 0.16 & 29.55 & 13.99 \\
\hline & Fruits per truss & & & & & 5.65 & - & 5.03 & 12.87 & 0.44 & 30.18 & 31.99 \\
\hline & Average fruit weight & & $* * *$ & $* * *$ & $* * *$ & 265 & - & 495.00 & 918 & 0.29 & 19.71 & 14.42 \\
\hline & Fruit length & & $* * *$ & $* * *$ & $* * *$ & 0.856 & - & 0.73 & 1.91 & 0.45 & 14.41 & 15.62 \\
\hline & Fruit diameter & & & $* *$ & $* * *$ & 0.113 & - & 0.34 & 0.5236 & 0.22 & 15.19 & 8.78 \\
\hline
\end{tabular}

Table 1. Variance components and genetic parameters for seven quantitative traits evaluated in the $F_{1}$ and $F_{3}$ populations.

$*, * *, * * *$ Significant at the $0.05,0.01,0.001$, probability levels, respectively.

$\mathrm{H}^{2}$ : Broad-sense heritability; $\mathrm{CV}_{\mathrm{P}}$ : phenotypic coefficient of variation; $\mathrm{CV}_{\mathrm{G}}$ : genotypic coefficient of variation. 


\section{Performance of $F_{1}$ hybrids, $F_{2}$ populations and $F_{3}$ families}

The mean performance of $F_{1}$ hybrids, $F_{2}$ populations and $F_{3}$ families is shown in Table 2. For the $F_{1}$ generation, the mean yield per plant ranged from $3038 \mathrm{~g}$ to $1715 \mathrm{~g}$. 'Cid' produced maximum fruit yield (3038 g plant $\left.{ }^{-1}\right)$, while 'Cuauhtémoc' and 'Loreto' had the lowest yields. Average number of fruits for plant across environments ranged from 19.69 fruits for 'Loreto' to 36.48 fruits for 'Cid'. For number of trusses per plant, 'Sun7705', 'Moctezuma', 'Cid' and 'Reserva' exhibited a higher number of trusses than 'Cuauhtémoc', 'Espartaco' and 'Loreto'. The range of number of fruits per truss varied from 7.67 fruits ('Espartaco' and 'Moctezuma') to 5.77 fruits ('Cuauhtémoc'). For average fruit weight, 'Cid' had the highest value (130 g), followed by 'Moctezuma' and 'Loreto' (123.5 and $118.4 \mathrm{~g}$, respectively), while the rest of hybrids had values that ranged from 103.2 to $116.7 \mathrm{~g}$. For fruit length and diameter, hybrids such as 'Espartaco' and 'Loreto' had the highest values for length and diameter, respectively, while 'Sun7705' had the lowest values.

According to the Tukey's test, means were nonsignificant $(\mathrm{P} \leq 0.05)$ for most of the traits in the $\mathrm{F}_{2}$ generation. Mean values ranged from 716.4 to $979.5 \mathrm{~g}$ for yield per plant, 11.31 to 12.94 fruits for number of fruits per plant, 2.13 to 2.72 trusses for number of trusses per plant, 6.50 to 8.43 fruits for number of fruits per truss, 87.80 to $106.60 \mathrm{~g}$ for average fruit weight, 5.99 to $6.76 \mathrm{~cm}$ for fruit length, and 4.21 to $4.80 \mathrm{~cm}$ for fruit diameter.

To know the average performance of $\mathrm{F}_{3}$ full-sib families by ancestral origin, the families were partitioned in function of their $\mathrm{F}_{1}$ varietal origin. According to Table 2, the families obtained from 'Loreto', 'Espartaco' and 'Cid', in average, were superior in yield per plant, number of fruit per plant, number of fruits per truss, average fruit weight and fruit diameter to the rest of the families derived from others tomato varieties. For number of trusses, families obtained from 'Loreto', 'Reserva' and 'Sun7705' exhibited a mean greater than the $\mathrm{F}_{3}$ population mean (3.96 trusses), while families from 'Cid', 'Cuauhtémoc' and 'Espartaco' had the lowest means.

Comparing the yield within each population across generations, we observed that some individuals of the $\mathrm{F}_{2}$ population and $F_{3}$ families exhibited a higher yield than the estimated mean of its $F_{1}$ hybrid parent (Figure 1). However, this situation

Table 2. Comparisons between means for yield and six yield components scored on seven $\mathbf{F}_{1}$ hybrid varieties, seven $\mathbf{F}_{2}$ populations and seven sets of $F_{3}$ families.

\begin{tabular}{|c|c|c|c|c|c|c|c|}
\hline \multirow[b]{2}{*}{ Variety } & \multicolumn{7}{|c|}{$F_{1}$ generation } \\
\hline & Yield plant $^{-1}$ & $\begin{array}{l}\text { Number of } \\
\text { fruits plant }^{-1}\end{array}$ & $\begin{array}{c}\text { Number of } \\
\text { trusses }\end{array}$ & $\begin{array}{l}\text { Number of } \\
\text { fruits truss }\end{array}$ & $\begin{array}{c}\text { Average } \\
\text { fruit weight }\end{array}$ & Fruit length & Fruit diameter \\
\hline & $\mathrm{g}$ & & & & $\mathrm{g}$ & $\mathrm{cm}$ & $\mathrm{cm}$ \\
\hline Cid & $3038.00 \mathrm{a}$ & $36.48 \mathrm{a}$ & $3.04 \mathrm{ab}$ & $7.76 \mathrm{a}$ & $130.00 \mathrm{a}$ & $7.19 a$ & $5.00 \mathrm{ab}$ \\
\hline Cuauhtémoc & $1813.00 \mathrm{c}$ & $22.37 d$ & $2.12 \mathrm{~d}$ & $5.77 b$ & $116.60 \mathrm{ab}$ & $7.07 \mathrm{a}$ & $4.80 \mathrm{abc}$ \\
\hline Espartaco & $2418.00 \mathrm{~b}$ & $31.24 b$ & $2.55 \mathrm{bcd}$ & $7.57 \mathrm{a}$ & $116.70 \mathrm{ab}$ & $7.33 \mathrm{a}$ & $4.65 \mathrm{~cd}$ \\
\hline Loreto & $1715.00 \mathrm{c}$ & $19.69 d$ & $2.43 \mathrm{~cd}$ & $6.60 \mathrm{ab}$ & $118.40 \mathrm{ab}$ & $6.47 \mathrm{c}$ & $5.04 \mathrm{a}$ \\
\hline Moctezuma & $1999.00 \mathrm{bc}$ & $23.44 d$ & $3.10 \mathrm{ab}$ & $7.57 \mathrm{a}$ & $123.50 \mathrm{ab}$ & $6.98 \mathrm{ab}$ & 4.79abc \\
\hline Reserva & $2029.00 \mathrm{bc}$ & $29.19 b c$ & $2.94 \mathrm{abc}$ & $7.00 \mathrm{ab}$ & $103.20 \mathrm{c}$ & $6.63 b c$ & $4.77 b c$ \\
\hline Sun7705 & $1930.00 \mathrm{bc}$ & $24.54 \mathrm{~cd}$ & $3.32 \mathrm{a}$ & 6.96ab & $110.20 \mathrm{bc}$ & $6.26 \mathrm{c}$ & $4.47 \mathrm{~d}$ \\
\hline Population & \multicolumn{7}{|c|}{$\mathrm{F}_{2}$ generation } \\
\hline Cid & 929.30 & 12.11 & 2.22 & 8.43 & $95.28 \mathrm{ab}$ & 6.72 & $4.28 b$ \\
\hline Cuauhtémoc & 807.30 & 12.03 & 2.26 & 7.86 & $94.98 \mathrm{ab}$ & 6.25 & $4.27 \mathrm{~b}$ \\
\hline Espartaco & 858.90 & 11.31 & 2.13 & 7.79 & $97.59 \mathrm{ab}$ & 6.50 & $4.33 b$ \\
\hline Loreto & 945.10 & 12.64 & 2.40 & 7.54 & $106.60 \mathrm{a}$ & 6.49 & $4.80 \mathrm{a}$ \\
\hline Moctezuma & 919.50 & 12.94 & 2.44 & 7.43 & $88.16 \mathrm{ab}$ & 5.99 & $4.21 \mathrm{~b}$ \\
\hline Reserva & 716.40 & 12.26 & 2.49 & 7.83 & $87.80 \mathrm{~b}$ & 6.76 & $4.37 \mathrm{ab}$ \\
\hline Sun7705 & 979.50 & 12.56 & 2.72 & 6.50 & $100.90 \mathrm{ab}$ & 6.69 & $4.31 \mathrm{~b}$ \\
\hline Families & \multicolumn{7}{|c|}{$\mathrm{F}_{3}$ generation } \\
\hline Cid & $1711.00 \mathrm{ab}$ & $19.55 \mathrm{ab}$ & $3.58 \mathrm{~b}$ & 8.28 & $121.30 \mathrm{a}$ & $7.23 \mathrm{a}$ & $3.63 \mathrm{bc}$ \\
\hline Cuauhtémoc & $1364.00 \mathrm{~b}$ & 18.19ab & $3.74 b$ & 7.70 & $105.00 \mathrm{bc}$ & $5.89 \mathrm{bc}$ & $3.59 \mathrm{bc}$ \\
\hline Espartaco & $1816.00 \mathrm{a}$ & $20.84 \mathrm{ab}$ & $3.78 b$ & 8.82 & $125.10 \mathrm{a}$ & $6.47 \mathrm{ab}$ & $4.09 \mathrm{a}$ \\
\hline Loreto & $1768.00 \mathrm{ab}$ & $22.35 \mathrm{a}$ & $4.72 \mathrm{a}$ & 8.26 & $111.70 \mathrm{ab}$ & $5.62 \mathrm{bc}$ & $3.81 \mathrm{abc}$ \\
\hline Moctezuma & 1399.00ab & $17.52 b$ & $3.64 b$ & 7.20 & $111.60 \mathrm{ab}$ & $5.37 \mathrm{c}$ & $3.97 \mathrm{ab}$ \\
\hline Reserva & $1343.00 \mathrm{~b}$ & $21.07 \mathrm{ab}$ & $4.24 \mathrm{ab}$ & 7.36 & $90.54 c$ & $5.35 \mathrm{c}$ & $3.53 \mathrm{c}$ \\
\hline Sun 7705 & $1338.00 \mathrm{~b}$ & $18.00 \mathrm{ab}$ & 4.16ab & 7.33 & $103.60 \mathrm{bc}$ & $5.72 b c$ & $3.72 \mathrm{abc}$ \\
\hline
\end{tabular}

Within each generation, means sharing same letters within the same column are nonsignificantly different according to Tukey's test $(\mathrm{P} \leq 0.05)$. 
Figure 1. Distribution of the observed yield per plant in $F_{1}$ hybrids, $F_{2}$ populations and $F_{3}$ families.

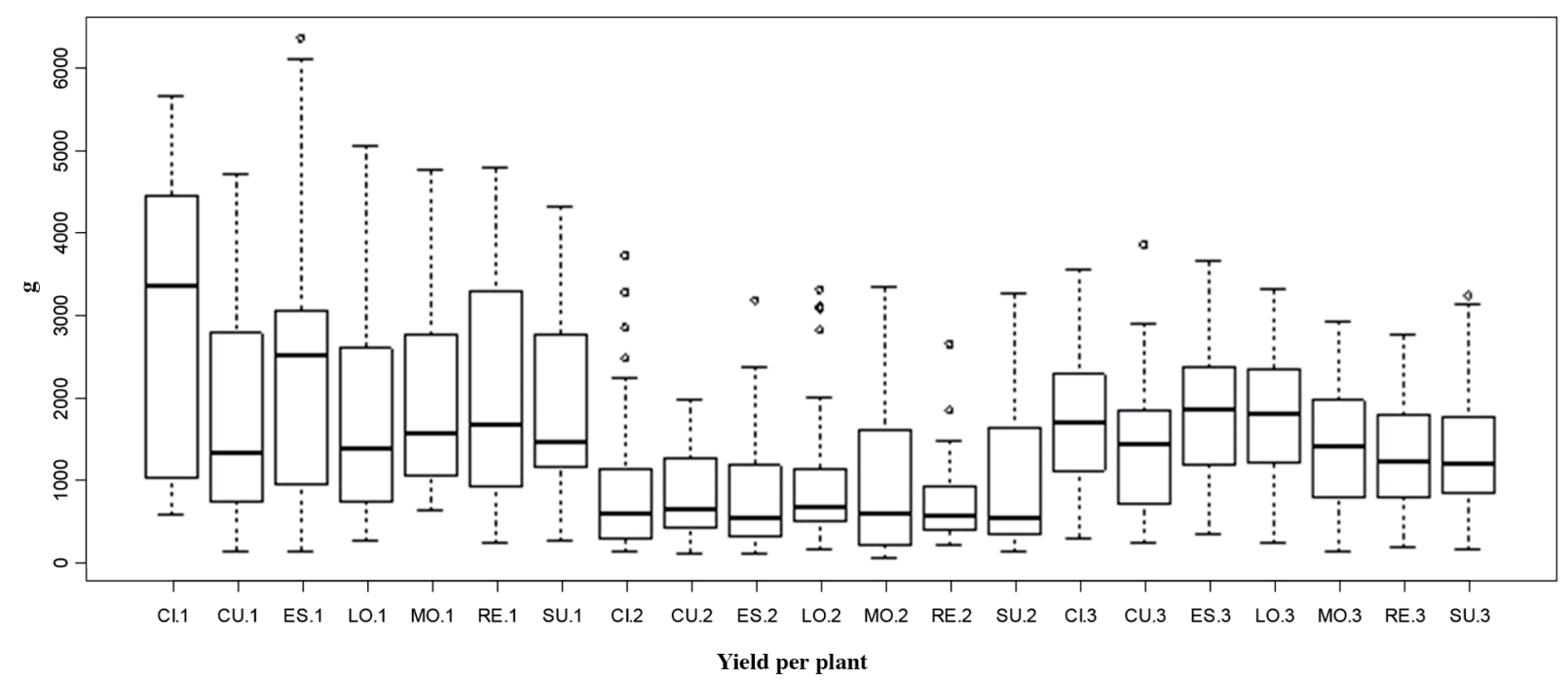

Cl: Cid, CU: Cuauhtémoc, ES: Espartaco, LO: Loreto, MO: Moctezuma, RE: Reserva, SU: Sun7705, 1: $F_{1}$ generation, 2: $F_{2}$ generation, and 3: $\mathrm{F}_{3}$ generation.

was more evident and frequent in the $\mathrm{F}_{3}$ families that in the $\mathrm{F}_{2}$ generation, where near of $50 \%$ of $\mathrm{F}_{3}$ individuals of 'Cuauhtémoc', 'Loreto', 'Moctezuma' showed a higher yield than the $F_{1}$ parental mean. In the rest of $F_{3}$ families also were detected some individual with a higher yield than its $F_{1}$ parental average.

\section{Genotype $\times$ Season interaction of $\mathbf{F}_{1}$ commercial hybrids}

According to the combined ANOVA for $\mathrm{F}_{1}$ (Table 1$)$, Genotype $\times$ Season interaction was significant $(\mathrm{P} \leq 0.05)$ for yield per plant, number of fruits per plant, number of trusses, average fruit weight, and fruit length. Tomato $F_{1}$ hybrids interacted in different magnitude with the season (Table 3 ). Considering $b_{i}$ and $\delta^{2} d_{i}$ stability statistics, a genotype with values of $b_{i}$ near to 1 and $\delta^{2} d_{i}$ near to 0 is considered to be stable (Eberhart and Russell, 1966). With exception of 'Moctezuma', most of the $F_{1}$ hybrids exhibited values near to the stability criteria in at least one trait. Specifically, the commercial hybrid named 'Cid' was stable for fruit length; 'Cuauhtémoc' for number of fruits per truss and fruit length; 'Espartaco' for number of fruits per plant and number of trusses; 'Loreto' for yield per plant, number of trusses, fruits per truss and fruit diameter; 'Reserva' for yield per plant, average fruit weight, fruit length and diameter; and 'Sun7705' for number of fruits per plant and number of trusses.

Table 3. Stability parameters for yield and six yield-components evaluated in seven tomato $F_{1}$ hybrids across the seasons 2011-2012.

\begin{tabular}{|c|c|c|c|c|c|c|c|c|c|c|c|c|c|c|}
\hline \multirow[b]{2}{*}{ Hybrid } & \multicolumn{2}{|c|}{ Yield plant $^{-1}$} & \multicolumn{2}{|c|}{$\begin{array}{l}\text { Number of fruits } \\
\text { plant }^{-1}\end{array}$} & \multicolumn{2}{|c|}{$\begin{array}{l}\text { Number of } \\
\text { trusses }\end{array}$} & \multicolumn{2}{|c|}{ Fruits truss $^{-1}$} & \multicolumn{2}{|c|}{$\begin{array}{l}\text { Average fruit } \\
\text { weight }\end{array}$} & \multicolumn{2}{|c|}{ Fruit length } & \multicolumn{2}{|c|}{ Fruit diameter } \\
\hline & $b_{i}$ & $\delta^{2} d_{i}$ & $b_{i}$ & $\delta^{2} d_{i}$ & $b_{i}$ & $\delta^{2} d_{i}$ & $b_{i}$ & $\delta^{2} d_{i}$ & $b_{i}$ & $\delta^{2} d_{i}$ & $b_{i}$ & $\delta^{2} \mathrm{~d}_{\mathrm{i}}$ & $b_{i}$ & $\delta^{2} d_{i}$ \\
\hline Cid & 1.36 & 225094.68 & 1.39 & 21.76 & 1.30 & 0.52 & 2.23 & -0.75 & 0.31 & 200.55 & 0.96 & -0.01 & 0.68 & -0.02 \\
\hline Cuauhtémoc & 0.85 & -76723.16 & 0.86 & 6.54 & 0.66 & -0.18 & 1.08 & -0.68 & 1.84 & -17.53 & 1.11 & -0.03 & 1.10 & -0.03 \\
\hline Espartaco & 1.18 & -151683.49 & 1.17 & -12 & 1.00 & -0 & 0.14 & -0 & 1.87 & -75.56 & 1.19 & -0.07 & 1.06 & -0.04 \\
\hline Loreto & 0.99 & -135268.98 & 0.77 & -13 & 1.02 & -0 & 1.05 & -0.73 & 0.67 & -91.24 & 0.87 & -0.09 & 1.05 & -0.04 \\
\hline Moctezuma & 0.90 & -128591.10 & 0.73 & 17 & 1.27 & -0 & 1.16 & -0 & 2.28 & 25 & 1.24 & 0.02 & 1.23 & -0.01 \\
\hline Reserva & 0.98 & -91590.90 & 1.24 & & 0.82 & -0.11 & 0.46 & -0.72 & 0.83 & -104.95 & 0.89 & -0.02 & 1.03 & -0.04 \\
\hline Sun7705 & 0.75 & -137513.38 & 0.85 & -13.22 & 0.94 & 0.01 & 0.88 & -0.04 & -0.81 & 29.03 & 0.75 & -0.06 & 0.85 & -0.01 \\
\hline
\end{tabular}

$b_{i}$ : Regression coefficient that measures the response of the $i^{\text {th }}$ variety to varying environments; $\delta^{2} d_{i}$ : deviation from regression of the $\mathrm{i}^{\text {th }}$ variety at $\mathrm{j}^{\text {th }}$ environment. 


\section{Genetic gain from $F_{2}$ to $F_{3}$}

Based on the individual selection performed on $\mathrm{F}_{2}$ generation, simultaneous positive gains were observed in most of the traits at $\mathrm{F}_{3}$ generation (Figure 2). In average, the highest positive gain was observed on yield per plant with a value of $73 \%$, followed by number of truss and number of fruits per plant with gains of $66 \%$ and $59 \%$, respectively. Average fruit weight and fruits per truss exhibited a positive gain less to $20 \%$. In contrast, fruit length and diameter had negative values of gains.

To evaluate the breeding potential of each $F_{1}$ hybrid, we estimated the genetic gain in their $F_{2}$ and $F_{3}$ progenies (Table 4). At $\mathrm{F}_{2}$, all populations exhibited a loss in genetic gain for yield per plant, number of fruits per plant, number of trusses, average fruit weight and fruit length, however, most of the populations exhibited a positive gain for number of fruits per truss. In general, the lowest values of genetic gain were found for yield and number of fruits per plant, evidencing a strong effect of inbreeding depression in both traits. When we measured the genetic gain from $F_{2}$ to $F_{3}$, a positive gain was detected in most of the $\mathrm{F}_{3}$ families for yield per plant, number of fruits per plant, number of trusses, number of fruits per truss, and average fruit weight. In particular, genetic gains for yield, number of fruits per plant and number of trusses were higher than those found for the rest of the traits.

Figure 2. Average genetic gain obtained from $F_{2}$ to $F_{3}$ for seven quantitative traits.

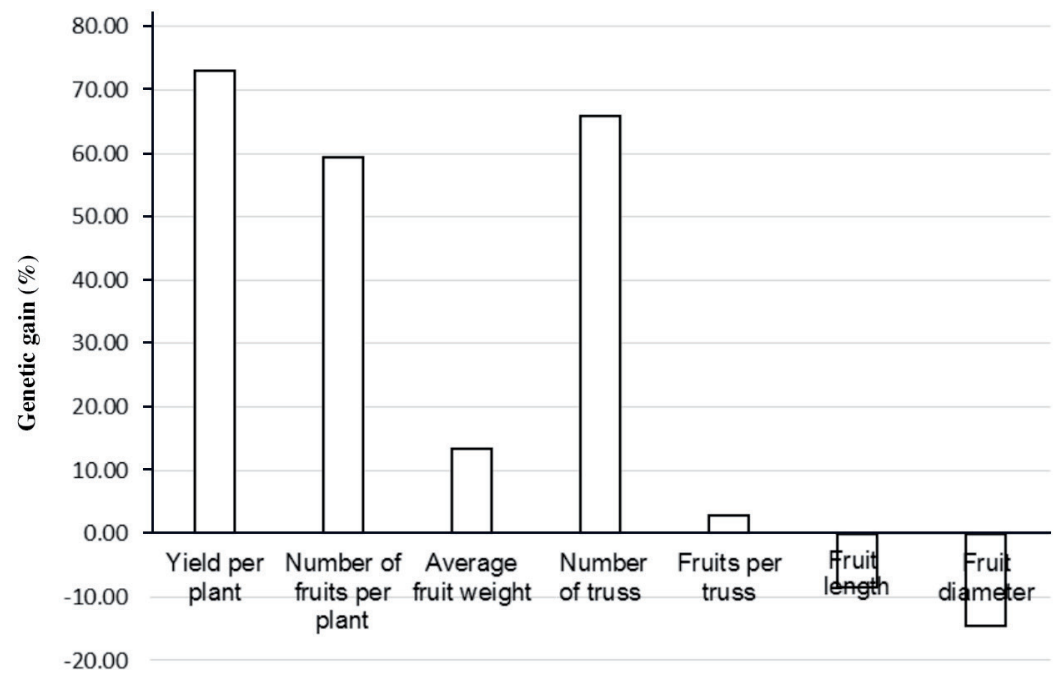

Table 4. Estimates of genetic gain by each $F_{2}$ population and set of $F_{3}$ families across generations.

\begin{tabular}{|c|c|c|c|c|c|c|c|c|}
\hline Generation & Population & $\begin{array}{l}\text { Number of } \\
\text { fruits plant }{ }^{-1}\end{array}$ & $\begin{array}{c}\text { Yield } \\
\text { plant }^{-1}\end{array}$ & $\begin{array}{l}\text { Number of } \\
\text { trusses }\end{array}$ & $\begin{array}{l}\text { Fruits } \\
\text { truss }^{-1}\end{array}$ & $\begin{array}{l}\text { Average fruit } \\
\text { weight }\end{array}$ & $\begin{array}{l}\text { Fruit } \\
\text { length }\end{array}$ & $\begin{array}{c}\text { Fruit } \\
\text { diameter }\end{array}$ \\
\hline \multirow[t]{7}{*}{$\mathrm{F}_{2}$} & Cid & -54.79 & -56.39 & -20.17 & 19.48 & -18.28 & -1.74 & -10.66 \\
\hline & Cuauhtémoc & -55.09 & -62.12 & -18.67 & 11.37 & -18.54 & -8.69 & -11.00 \\
\hline & Espartaco & -57.78 & -59.69 & -23.55 & 10.37 & -16.30 & -4.97 & -9.64 \\
\hline & Loreto & -52.81 & -55.65 & -13.78 & 6.85 & -8.58 & -5.15 & 0.19 \\
\hline & Moctezuma & -51.70 & -56.85 & -12.31 & 5.31 & -24.39 & -12.43 & -12.19 \\
\hline & Reserva & -54.23 & -66.38 & -10.62 & 11.03 & -24.70 & -1.22 & -8.89 \\
\hline & Sun7705 & -53.11 & -54.03 & -2.36 & -7.86 & -13.46 & -2.31 & -10.04 \\
\hline Generation & Families & $\begin{array}{l}\text { Number of } \\
\text { fruits plant }{ }^{-1}\end{array}$ & $\begin{array}{c}\text { Yield } \\
\text { plant }^{-1}\end{array}$ & $\begin{array}{l}\text { Number of } \\
\text { trusses }\end{array}$ & $\begin{array}{l}\text { Fruits } \\
\text { truss }^{-1}\end{array}$ & $\begin{array}{l}\text { Average fruit } \\
\text { weight }\end{array}$ & $\begin{array}{l}\text { Fruit } \\
\text { length }\end{array}$ & $\begin{array}{c}\text { Fruit } \\
\text { diameter }\end{array}$ \\
\hline \multirow[t]{7}{*}{$\mathrm{F}_{3}$} & Cid & 59.29 & 94.44 & 50.05 & 9.02 & 25.85 & 11.24 & -17.39 \\
\hline & Cuauhtémoc & 48.21 & 55.00 & 56.63 & 1.37 & 8.94 & -9.43 & -18.12 \\
\hline & Espartaco & 69.80 & 106.37 & 58.35 & 16.11 & 29.80 & -0.42 & -6.81 \\
\hline & Loreto & 82.10 & 100.91 & 97.71 & 8.73 & 15.89 & -13.56 & -13.10 \\
\hline & Moctezuma & 42.75 & 58.98 & 52.69 & -5.29 & 15.79 & -17.40 & -9.53 \\
\hline & Reserva & 71.67 & 52.62 & 77.59 & -3.18 & -6.06 & -17.77 & -19.67 \\
\hline & Sun7705 & 46.66 & 52.05 & 74.24 & -3.49 & 7.49 & -11.96 & -15.31 \\
\hline
\end{tabular}




\section{DISCUSSION}

A wide parental phenotypic variance with a great genotypic component is required to obtain a significant genetic gain per selection cycle (Acquaah, 2012). Here, $F_{1}$ varieties and $F_{3}$ families exhibited significant differences for most of the traits, indicating the presence of significant phenotypic variance in both populations. For both generations, the coefficient of phenotypic variability for yield per plant, number of fruits per plant, number of trusses and fruits per truss was higher compared with the rest of the traits, suggesting that the studied populations have a higher variability in vegetative traits and yield than in fruit size and shape. Our phenotypic and genotypic coefficients of variability were less to those reported by Adewale and Adebo (2018), who evaluated tomato landraces and reported variability coefficients superiors to $67.38 \%$. Such comparison confirm that the phenotypic and genotypic variation is broader in landraces that in commercial varieties tested.

In plant breeding, genetic gain is affected by the heritability of the trait, the selection intensity used and the phenotypic variation present in the population (Acquaah, 2012). In general, our genetic gains were higher for yield per plant, number of truss and number of fruits per plant than for average fruit weight, fruits per truss, fruit length and diameter. Such results were consistent with the values of the coefficients of variation found in the traits in $F_{1}$, as those traits with high phenotypic and genotypic coefficients of variation exhibited a high genetic gain from $\mathrm{F}_{2}$ to $\mathrm{F}_{3}$. Bernardo (2002) establishes that a genotype is considerate with good breeding value when their progeny exhibits a good performance for traits of interest. In our study, hybrids as 'Cid', 'Espartaco' and 'Reserva' had the highest yield and number of fruits per plant in the $F_{1}$ generation, however, their $F_{2}$ progenies did not exhibited the highest genetic gains for both traits. Although the $F_{2}$ populations from 'Cid' and 'Espartaco' exhibited a poor average performance, their $\mathrm{F}_{3}$ families exhibited high genetic gains for number of fruits per plant, yield per plant, number of fruits per truss, average fruit weight and length. Concerning 'Loreto', an interesting situation was observed in their populations; $F_{1}$ hybrid exhibited the lowest yield but their $F_{3}$ families had the highest yield. These results suggested that the best $\mathrm{F}_{3}$ families can be obtained by selection not only from high-yielding $\mathrm{F}_{1}$ hybrids but also from low-yielding hybrids. Based on the observed agronomic performance of $\mathrm{F}_{3}$ families derived from high-yielding $F_{1}$ hybrids, our results supported the findings of Kallo et al. (1974) in tomato, who established that parental per se performance is a reliable parameter for obtaining high-yielding progeny.

There is evidence of transgressive segregation in tomato (Shivaprasad et al., 2012), which can generate the obtaining plants with larger fruits than their parents (Hernández-Leal et al., 2013). In the evaluation of $\mathrm{F}_{3}$ families, we observed that the average number of fruits per truss was higher than that found in $F_{1}$ and $F_{2}$. Such result evidenced the presence of transgressive segregations in tomato, where some $\mathrm{F}_{2}$ plants had a high accumulation of positive alleles for number of fruits per truss. In addition, same situation was found in the $\mathrm{F}_{3}$ families of 'Loreto' for yield and number of fruits per plants.

Previous studies report that the genotype-by-environment interaction is a factor determining the agronomic performance of some tomato genotypes (Ortiz et al., 2007). In the present study, the $F_{1}$ varieties significantly interacted with the environment for most of the traits evaluated, suggesting that the environmental effects play an important role in the expression of phenotypic value in the varieties tested. Such results were consistent with those reported by Al-Aysh (2014) and Tiwari and Lal (2014), who found that traits as yield per plant, number of fruits per plant and average fruit weight interacted significantly with environment. We observed that tomato varieties interacted in different magnitude with environment. Based on the parameters established by Eberhart and Russell (1966), none hybrids were stable for all traits. However, hybrids as 'Loreto' and 'Reserva' were stable for yield per plant through growth cycles. In Mexico, 'Loreto' and 'Reserva' are growth in commercial production systems localized in a wide range of altitude. All previous results suggest that 'Loreto' and 'Reserva' have a good phenotypic plasticity for a wide range of environments. However, yield and number of fruits per plant exhibited by 'Loreto' and 'Reserva' were lower than those observed in 'Cid' and 'Espartaco'. For this reason, 'Cid' and 'Espartaco' could be considerate as varieties for the production systems localized at highlands.

In the current study, the estimations of heritability were higher for $F_{3}$ than for $F_{1}$. Heritability for yield per plant, number of fruits per plant and number of trusses was found to be within the range from 0.08 to 0.21 . This suggested that these three traits presented a low heritability. Such results are in agreement with the findings of El-Gabry et al. (2014) for number of fruits per plant and Hernández-Bautista et al. (2015) for yield per plant. Concerning fruit size related-traits, heritability estimates were unstable across generations as these were low in $F_{1}$ but intermediate in $F_{3}$. Such pattern was due to variation observed for fruit shape and size in each generation. Specifically, in $F_{1}$ all varieties showed an elliptic shape 
and fruit weight and size almost similar, while for $\mathrm{F}_{2}$ and $\mathrm{F}_{3}$ the phenotypic diversity regarding to fruit shape and size was wider due to the Mendelian segregation. For both $F_{1}$ and $F_{3}$ generations, heritability estimates for fruit related-traits were found to be within the range from low to intermedium, suggesting that most part of the observed phenotypic variability was due to environmental effects. Our results were in agreement with the findings of Hernández-Bautista et al. (2014) for average fruit weight. In contrast, Meitei et al. (2014) and Somraj et al. (2017) reported a high heritability for fruits weight and size. The justification of these different results is due to amount of genotypic variance present in the population tested and environmental variance captured by the experimental error, as large genetic variance and a low environmental variance lead to high estimations of heritability.

\section{CONCLUSIONS}

Most of the $F_{1}$ hybrids exhibited values of stability across seasons in at least one trait. However, 'Loreto' and 'Reserva' only exhibited a high stability for yield, which evidences its good phenotypic plasticity to be cultivated in highlands. In general, heritability estimates were found to be low or intermediate. In addition, it was observed that the tested populations exhibited a wider phenotypic diversity for fruit yield than for fruit-related traits.

The results obtained in this study indicated that some $F_{1}$ hybrids are an excellent source of germplasm for the obtainment of $\mathrm{F}_{3}$ families. In particular, the $\mathrm{F}_{1}$ hybrids as 'Cid', 'Espartaco' and 'Loreto' exhibited a high breeding potential for yield, number of fruits per plant, number of fruits per plant and average fruit weight. Based on these results, we conclude that the use of commercial hybrids in a breeding scheme by pedigree selection generates materials with important genetic advances in yield and other traits.

\section{ACKNOWLEDGEMENTS}

The authors would like to thank The National Council of Science and Technology of Mexico (CONACyT) and the Colegio de Postgraduados, Campus Montecillo for financing this work.

\section{REFERENCES}

Acquaah, G. 2012. Principles of plant genetics and breeding. $2^{\text {nd }}$ ed. Wiley-Blackwell, Oxford, UK.

Adewale, B.D., and Adebo, U.G. 2018. Phenotypic identity, similarity and stability for selection of tomatoes (Lycopersicon esculentum L.) cultivars in South-western Nigeria. Scientia Horticulturae 235:264-269.

Al-Aysh, F.M. 2014. Genotype-environment interaction and phenotypic stability for fruit yield and its productive components of tomato. Journal of Recent Advances in Agriculture 2:219-226.

Avdikos, I.D., Tsivelika, N., Gallidou, A., Koutsika-Sotiriou, M., and Traka-Mavrona, E. 2011 . Exploitation of heterosis through recurrent selection scheme applied in segregating generations of a tomato breeding program. Scientia Horticulturae 130:701-707.

Bernardo, R. 2002. Breeding for quantitative traits in plants. Stemma Press, Woodbury, Minnesota, USA.

Eberhart, S.A., and Russell, W.A. 1966. Stability parameters for comparing varieties. Crop Sciences 6:36-40.

El-Gabry, M.A.H., Solieman, T.I.H., and Abido, A.I.A. 2014. Combining ability and heritability of some tomato (Solanum lycopersicum L.) cultivars. Scientia Horticulturae 167:153-157.

FAO. 2014. FAO statistical yearbook. Food and Agriculture Organization (FAO) of the United Nations, Rome, Italy. Available at http://faostat.fao.org (accessed September 2017).

Foolad, M.R., and Panthee, D.R. 2012. Marker-assisted selection in tomato breeding. Critical Reviews in Plant Sciences 31:93-123.

Hernández-Bautista, A., Lobato, O.R., Cruz, I.S., García, Z.J.J., y Chávez, S.J.L. 2014. Variación fenotípica, heterosis y heredabilidad de una cruza interespecífica de jitomate. Interciencia 39:327-332.

Hernández-Bautista, A., Lobato, O.R., Cruz, I.S., García, Z.J.J., Chávez, S.J.L., Hernández, L.E., et al. 2015. Fruit size QTLs affect in a major proportion the yield in tomato. Chilean Journal of Agricultural Research 75:402-409.

Hernández-Leal, E., Lobato-Ortiz, R., García-Zavala, J.J., Reyes-López, D., Méndez-López, A., Bonilla-Barrientos, O., et al. 2013. Comportamiento agronómico de poblaciones $\mathrm{F}_{2}$ de híbridos de tomate (Solanum lycopersicum L.) Revista Fitotecnia Mexicana 36:209-215.

Kallo, G., Singh, R.K., and Bhutani, R.D. 1974. Combining ability studies in tomato (Lycopersicon esculentum Mill.) Theoretical Applied Genetics 44:358-363. 
Kumar, R., Srivastava, K., Singh, N.P., Vasistha, N.K., Singh, R.K., and Singh, M.K. 2013. Combining ability analysis for yield and quality traits in tomato (Solanum lycopersicum L.) Journal of Agricultural Sciences 5:213-218.

Martínez-Vázquez, E., Hernández, B.A., Lobato, O.R., García, Z.J.J., and Reyes, L.D. 2017. Exploring the breeding potential of Mexican tomato landraces. Scientia Horticulturae 220:317-325.

Masheva, S. 2014. Recent trends of the breeding programs in main vegetables and potatoes in Bulgaria. Journal of Horticulture 1:1-3.

Meitei, K.M., Bora, G.C., Singh, S.J., and Sinha, A.K. 2014. Morphology based genetic variability analysis and identification of important characters for tomato (Solanum lycopersicum L.) crop improvement. American-Eurasian Journal of Agricultural and Environmental Sciences 14:1105-1111.

Nalley, L., Tack, J., Barkley, A., Jagadish, K., and Brye, K. 2016. Quantifying the agronomic and economic performance of hybrid and conventional rice varieties. Agronomy Journal 108:1514-1523.

Ortiz, R., Crossa, J., Vargas, M., and Izquierdo, J. 2007. Studying the effect of environmental variables on the genotype $\times$ environment interaction of tomato. Euphytica 153:119-134.

SAGARPA. 2017. Secretaría de Agricultura, Ganadería, Desarrollo Rural, Pesca y Alimentación (SAGARPA), Ciudad de México, México. Available at http://www.sagarpa.gob.mx/saladeprensa/2012/ Paginas/2015B466.aspx (accessed June 2017).

SAS Institute. 2011. User's guide of SAS/IML (Statistical Analysis System). SAS Institute, Cary, North Carolina, USA.

Shivaprasad, P.V., Dunn, R.M., Santos, B.A., Bassett, A., and Baulcombe, D.C. 2012. Extraordinary transgressive phenotypes of hybrid tomato are influenced by epigenetics and small silencing RNAs. The EMBO Journal 31:257-266.

SIAP. 2015. Producción Agropecuaria y Pesquera. Sistema de Información Agroalimentaria y Pesquera (SIAP), Ciudad de México, México. Available at http://www.siap.gob.mx/ (accessed April 2015).

Somraj, B., Reddy, R.V.S.K., Reddy, K.R., Saidaiah, P., and Reddy, M.T. 2017. Genetic variability, heritability and genetic advance for yield and quality attributes in heat tolerant exotic lines of tomato (Solanum lycopersicum L.) Journal of Pharmacognosy and Phytochemistry 6:1956-1960.

Tiwari, A.K., and Lal, G. 2014. Genotype-environment interaction and stability analysis in tomato (Solanum lycopersicum L.) Indian Journal of Hill Farming 27:16-18. 